\section{Photosynthesis and Growth of Rhamnus caroliniana during Drought and Flooding: Comparisons to the Invasive Rhamnus cathartica}

\author{
J. Ryan Stewart ${ }^{1}$ and William R. Graves \\ Department of Horticulture, Iowa State University, Ames, IA 50011-1100
}

Additional index words. carolina buckthorn, indian cherry, common buckthorn, water use, stress tolerance, inundation, waterlogging

\begin{abstract}
Rhamnus caroliniana Walt. (carolina buckthorn or indian cherry) is an attractive small tree or shrub found in diverse habitats in the United States. Because the species occurs in both mesic and xeric soils, we questioned whether selections of carolina buckthorn could be marketed as new nursery crops resistant to both drought and flooding. Our first objective was to characterize how soil water affects growth and gas exchange of carolina buckthorn. We studied potted plants subjected to soil moistures that ranged from complete submersion of the root zone to severe drought ( $7 \%$ soil water by volume). The maximal photosynthetic rate occurred at $27 \%$ soil water content, and complete submersion killed plants. Our second objective was to compare responses of carolina buckthorn to those of the invasive common buckthorn (Rhamnus cathartica L.) when potted plants were treated with partial flooding of root zones and drought. Carolina buckthorn resisted deleterious effects of partial flooding. In contrast, leaves of common buckthorn became epinastic, and rates of photosynthesis were low $\left(2.14 \mu \mathrm{mol} \mathrm{CO} / \mathrm{Cm}^{2} / \mathrm{s}\right)$ after 17 days of treatment. Mean photosynthesis of common buckthorn increased to $5.52 \mu \mathrm{mol} \mathrm{CO} / \mathrm{C}^{2} / \mathrm{s}$, a rate similar to that of carolina buckthorn, after 55 days of treatment. Drought reduced net photosynthesis by $52 \%$ and $68 \%$, respectively, for carolina buckthorn and common buckthorn relative to rates of plants in the control treatment. We conclude that carolina buckthorn is capable of maintaining carbon fixation and growth over a wide range of soil water contents, and unlike common buckthorn, is not dependent upon morphological, anatomical, or physiological adjustments to optimize growth and net photosynthesis in extremely wet soil. Use of carolina buckthorn as an ornamental is warranted if invasiveness and other potential problems with the species are not identified.
\end{abstract}

Carolina buckthorn is used rarely in horticultural landscapes but is a distinctive shrub or small tree native to the Lower Midwestern and southeastern United States. In its natural range, carolina buckthorn occurs on alluvial soils as well as on dry, upland, limestone ridges (Brown and Kirkman, 1990; Foote and Jones, 1989). The various soil conditions associated with indigenous carolina buckthorn imply that the species is adapted to diverse soil water contents typical of managed landscapes. However, the response of carolina buckthorn to extreme soil moisture has not been evaluated.

The resistance of carolina buckthorn to different soil water contents will help to define how the species might be used horticulturally. But, regardless of its resilience in poor soils, acceptance of carolina buckthorn as a new horticultural crop for landscaping also will depend on other factors, most notably its potential to be invasive. All species commonly called buckthorns (the entire Rhamnus L. genus)

Received for publication 6 Aug. 2003. Accepted for publication $22 \mathrm{Jan}$. 2004. This is a publication of the Iowa Agriculture and Home Economics Experiment Station, Project 3603. We thank Lou Anella, Bob Deal, and Merv Wallace for seed collection. We are also grateful to Mark Kroggel for assistance with data collection and statistical analysis.

'Corresponding author; e-mail stewart@iastate.edu. often are assumed to be invasive even though most problems in North America have resulted from only two species, Rhamnus cathartica L. (common buckthorn) (Archibold et al., 1997; Gourley, 1985) and Rhamnus frangula L. (glossy buckthorn) (Catling and Porebski, 1994). The introduction of these species to North America from other continents has led to negative consequences for natural ecosystems in some regions. In a southern Wisconsin urban forest, Harrington et al. (1989) found that common buckthorn had greater midday photosynthetic rates ( 9 to $13 \mu \mathrm{mol} \mathrm{CO} / \mathrm{m}^{2} / \mathrm{s}$ ) than a native woody species, Cornus racemosa Lam. In a forest near Ottawa, Ont., Berry et al. (1997) found that glossy buckthorn had a midday photosynthetic rate of $7 \mu \mathrm{mol} \mathrm{CO}_{2} / \mathrm{m}^{2} / \mathrm{s}$, which was, on average, $97 \%$ greater than that of the other three understory species studied. Such observations, along with the lack of ornamental appeal of several Rhamnus spp., may explain why buckthorns rarely are grown or used by horticulturists.

We believe the outstanding growth habit, fruit display, and foliar traits of carolina buckthorn (Graves, 2001) make it an ornamentally superior member of its genus. Whether the species may become invasive has not been resolved, but knowing how resistant carolina buckthorn is to a range of soil water contents will be useful to those assessing the habitats in which the unintended escape and spread of the species might be possible. Thus, our rationale for studying how carolina buckthorn responds to soil-water conditions is 2-fold. Our data will aid horticulturists by helping to define preferred soil conditions for carolina buckthorn used for ornamental landscaping and will aid ecologists who are assessing the invasiveness potential of the species. Our specific objectives were to determine how root-zone water content affects gas exchange and growth of carolina buckthorn and to contrast these responses to those of common buckthorn. The widespread region of North America where common buckthorn is naturalized includes Missouri, Illinois, Indiana, and Ohio, states where carolina buckthorn is indigenous. Our rationale for comparing these two species included their partially sympatric occurrence, the capacity of both to persist in diverse habitats (Brown and Kirkman, 1990; Foote and Jones, 1989; Soper and Heimburger, 1982), and the opportunity to contrast carolina buckthorn to a closely related species known to be invasive.

\section{Materials and Methods}

Effects of soil water content on gas exchange and growth of carolina buckthorn. In total, 30 full-sibling, 4-month-old carolina buckthorns indigenous to Johnston County, Okla. (lat. $34^{\circ} 19^{\prime} 40^{\prime \prime} \mathrm{N}$; long. $96^{\circ} 42^{\prime} 20^{\prime \prime} \mathrm{W}$ ) were grown in a greenhouse. Leaf area of five randomly chosen seedlings was determined on $1 \mathrm{Aug}$. 2000 with a leaf area meter (model 3100; LI-COR, Lincoln, Nebr.), and roots, stems, and leaves were separated, washed, dried in an oven at $67^{\circ} \mathrm{C}$ for $3 \mathrm{~d}$, and weighed. These data were used to assess treatment effects on growth of the remaining seedlings, which were cultured in $3.44-\mathrm{L}$ pots (height $=16 \mathrm{~cm}$, top diameter $=20.3 \mathrm{~cm}$ ) filled with 5 sphagnum peat : 3 perlite : 2 silt loam soil (by volume). Each pot was placed in a 6.19-L pot (height $=$ $21.6 \mathrm{~cm}$, top diameter $=21.6 \mathrm{~cm}$ ) to facilitate flooding the root zone of some plants while sustaining similar root-zone temperatures for all plants. Five treatments (severe drought, moderate drought, moist, wet, and flooded) assigned randomly to 25 plants $(n=5)$ were imposed in a greenhouse from 1 Aug. through 18 Sept. 2000 . We irrigated to the water-holding capacity of drained root zones every 12 , 8 , and $4 \mathrm{~d}$ for plants in the severe-drought, moderate-drought, and moist treatments, respectively. The lower portion of the root zone of plants in the wet treatment was saturated continuously within a 2.5 -cm-high saucer filled with tap water. Entire root zones in the flooded treatment were immersed in tap water by sealing the drainage holes in the 6.19 -L pots and keeping the water column at the surface of the medium in the 3.44-L pots.

All plants were fertilized on 25 Aug. with $11.0 \mathrm{~mm} \mathrm{~N}$ from a mixture of Peters Excel AllPurpose and Cal-Mag (16.5N-2.2P-13.5K) (Scotts, Marysville, Ohio) in tap water. This was the first day when plants in the moist, moderate-drought, and severe-drought treatments were scheduled for irrigation on the same date. Root zones in the wet and flooded 
Table 1. Mean photosynthetic rate, leaf area, plant dry weight, root-to-shoot ratio, relative growth rate, and net assimilation rate of potted Rhamnus caroliniana Walt. (carolina buckthorn) plants assigned to five soil-water treatments that were based on irrigation frequency. Treatments were imposed from 1 Aug. 2000 until 18 Sept. 2000. There were five single-plant replications per treatment.

\begin{tabular}{|c|c|c|c|c|c|c|c|c|c|}
\hline \multirow[b]{3}{*}{ Treatment } & \multicolumn{9}{|c|}{ Dependent variable } \\
\hline & \multirow{2}{*}{$\begin{array}{c}\text { Photosynthetic rate } \\
\left(\mu \mathrm{mol} \mathrm{CO} / \mathrm{m}^{2} / \mathrm{s}\right)\end{array}$} & \multirow{2}{*}{$\begin{array}{l}\text { Leaf area } \\
\left(\mathrm{cm}^{2}\right)\end{array}$} & \multicolumn{4}{|c|}{ Dry wt (g) } & \multirow{2}{*}{$\begin{array}{l}\text { Root-to-shoot } \\
\text { ratio }\end{array}$} & \multirow{2}{*}{$\begin{array}{l}\text { Relative growth } \\
\text { rate }\left(\mathrm{g} \cdot \mathrm{kg}^{-1} \cdot \mathrm{d}^{-1}\right)\end{array}$} & \multirow{2}{*}{$\begin{array}{l}\text { Net assimilation } \\
\text { rate }\left(\mathrm{g} \cdot \mathrm{cm}^{-2} \cdot \mathrm{d}^{-1}\right)\end{array}$} \\
\hline & & & Root & Stem & Leaf & Total & & & \\
\hline \multicolumn{10}{|l|}{$\overline{\text { Drought }}$} \\
\hline Severe & $0.5 \mathrm{~b}^{\mathrm{z}}$ & $1252 \mathrm{~b}$ & $4.4 \mathrm{abc}$ & $7.5 \mathrm{bc}$ & $7.5 \mathrm{~b}$ & $19.4 \mathrm{~b}$ & $0.3 \mathrm{a}$ & $7.2 \mathrm{bc}$ & $0.9 \mathrm{~b}$ \\
\hline Moderate & $1.7 \mathrm{ab}$ & $1332 \mathrm{~b}$ & $5.9 \mathrm{ab}$ & $7.7 \mathrm{~b}$ & $8.1 \mathrm{~b}$ & $21.7 \mathrm{ab}$ & $0.4 \mathrm{a}$ & $9.2 \mathrm{ab}$ & $1.2 \mathrm{ab}$ \\
\hline Moist & $2.9 \mathrm{a}$ & $2235 \mathrm{a}$ & $8.8 \mathrm{a}$ & $10.5 \mathrm{a}$ & $13.2 \mathrm{a}$ & $32.5 \mathrm{a}$ & $0.4 \mathrm{a}$ & $17.1 \mathrm{a}$ & $3.0 \mathrm{a}$ \\
\hline Wet & $1.4 \mathrm{ab}$ & $930 \mathrm{~b}$ & $2.7 \mathrm{bc}$ & $5.1 \mathrm{c}$ & $5.4 \mathrm{~b}$ & $13.3 \mathrm{~b}$ & $0.3 \mathrm{a}$ & $-0.5 \mathrm{c}$ & $0.1 \mathrm{~b}$ \\
\hline Flooded & $0.0 \mathrm{~b}$ & $0 \mathrm{c}$ & $0.0 \mathrm{c}$ & $0.0 \mathrm{~d}$ & $0.0 \mathrm{c}$ & $0.0 \mathrm{c}$ & $0.0 \mathrm{~b}$ & $0.0 \mathrm{c}$ & $0.0 \mathrm{c}$ \\
\hline
\end{tabular}

${ }^{2}$ Treatment means within each column followed by the same letter are not different at $P \leq 0.05$ according to Tukey's honestly significant difference test.

treatments were flushed with fertilizer solution after briefly removing the $3.44-\mathrm{L}$ pots from the 6.19-L pots. Two 400-W, high-pressure sodium lamps provided supplementary irradiance $(90$ $\mu \mathrm{mol} \cdot \mathrm{m}^{-2} \cdot \mathrm{s}^{-1}$ ) between 0600 and $2200 \mathrm{HR}$. We used a datalogger (model CR23X; Campbell Scientific, Logan, Utah) equipped with a probe (model CS500; Campbell Scientific) and a quantum sensor (model LI190SB; LI-COR) to determine mean air temperature $\left(25.7^{\circ} \mathrm{C}\right)$, mean relative humidity $(56.6 \%)$, and mean photosynthetically active radiation during photoperiods $\left(215 \mathrm{\mu mol} \cdot \mathrm{m}^{-2} \cdot \mathrm{s}^{-1}\right)$.

Net photosynthesis of the youngest fully expanded leaf of the longest stem of each plant was measured with a photosynthesis system (LI-6400; LI-COR) before irrigating on 25 Aug. and on 18 Sept. (the final day of treatment). Water content by volume of the upper $6 \mathrm{~cm}$ of the root zones was determined simultaneously with a ThetaProbe (model ML1;Delta-TDevices, Cambridge, U.K.).Leaf area and dry mass of roots, stems, and leaves were determined after roots were cleaned on 18 Sept. All tissues were oven-dried for $3 \mathrm{~d}$ at $67{ }^{\circ} \mathrm{C}$. We also determined relative growth and net assimilation rates (Harper, 1977). All data were collected in a random order without regard to treatment.

Data were analyzed by using the general linear models procedure and Tukey's honestly significant difference option of SAS/STAT software Version 8.2 (1999-2001) (SAS Inst., Cary, N.C.). We used regression analysis to determine the soil water content at which net photosynthesis was maximal.

Comparison of carolina buckthorn and common buckthorn. Seeds of carolina buckthorn were collected from one plant in Cook Station, Mo. (lat. 3748'46”N; long. 91 ${ }^{\circ} 26^{\prime} 16^{\prime \prime} \mathrm{W}$ ), one plant in Brazito, Mo. (lat. 38 26'44'N; long. $\left.92^{\circ} 18^{\prime} 9^{\prime \prime} \mathrm{W}\right)$, and two plants in Adams Co., Ohio (lat. $38^{\circ} 40^{\prime} 25^{\prime \prime} \mathrm{N}$; long. $83^{\circ} 27^{\prime} 10^{\prime \prime} \mathrm{W}$ ). Seeds also were collected from the plant from Oklahoma that was the seed source for the first experiment. The seeds were stratified in Fall 2000 and germinated in a greenhouse. Experimental units were first-year seedlings from each of the five maternal parents. The three provenances provided intraspecific variation. Seeds of common buckthorn from five plants naturalized in Ames, Iowa (lat. 42 2' 5' N; long. $\left.93^{\circ} 37^{\prime} 11^{\prime \prime} \mathrm{W}\right)$ were stratified, and seedlings were produced, by using the same procedures and schedule used for carolina buckthorn. All plants were grown in 1.64-L pots (height $=$
$15.2 \mathrm{~cm}$, top diameter $=15.2 \mathrm{~cm}$ ) containing Fafard mix \#3-BF (Fafard, Anderson, S.C.). In total, 30 plants ( 15 per species, 3 per sibling group) were randomly assigned to each of three treatments (control, drought, and partial flood). The 90 plants were treated from 1 Aug. through 16 Oct. 2001.

We monitored water content of root zones with the sensor used during the first experiment. Control plants were irrigated when mean soil water content of root zones for both species decreased to $27 \%$, which was the soil water content at which maximal net photosynthesis occurred in the first experiment. Plants in the partial-flood treatment were held in $18-\mathrm{cm}$-diameter saucers that contained a 7.2-cm column of tap water that entered root zones via drainage holes in the bottom of the pots. When mean water content of root zones in the drought treatment decreased to $10 \%$, we fertilized all plants with a solution of the same fertilizer and concentration used during the first experiment. This was done on 1, 17, and 31 Aug.; 12 and 25 Sept.; and 5 and 16 Oct., dates that defined the end of repeated drought cycles. Before fertilization on each day a drought cycle ended, net photosynthesis and root-zone water were measured as during the first experiment. Supplementary irradiance was provided by four $400-\mathrm{W}$, high-pressure sodium lamps $\left(116 \mu \mathrm{mol} \cdot \mathrm{m}^{-2} \cdot \mathrm{s}^{-1}\right)$. The environment was monitored as during the first experiment. Air averaged $25.5{ }^{\circ} \mathrm{C}$, mean relative humidity was $60.1 \%$, and mean photosynthetically active radiation during photoperiods was 344 $\mu \mathrm{mol} \cdot \mathrm{m}^{-2} \cdot \mathrm{s}^{-1}$. The procedures used during the first experiment were followed as we harvested plants destructively on 16 Oct.

We analyzed data by using the general linear models procedure and Tukey's honestly significant difference option (SAS Inst.). Regression analysis was performed to test for effects of duration of partial flooding on net photosynthesis of both species. Data from carolina buckthorn also were analyzed separately from those of common buckthorn to assess for differences between provenances.

\section{Results}

Effects of soil water content on gas exchange and growth of carolina buckthorn. All flooded plants died, most within the first $25 \mathrm{~d}$ of treatment, and all plants in the other four treatments survived. Leaves of the flooded plants began to

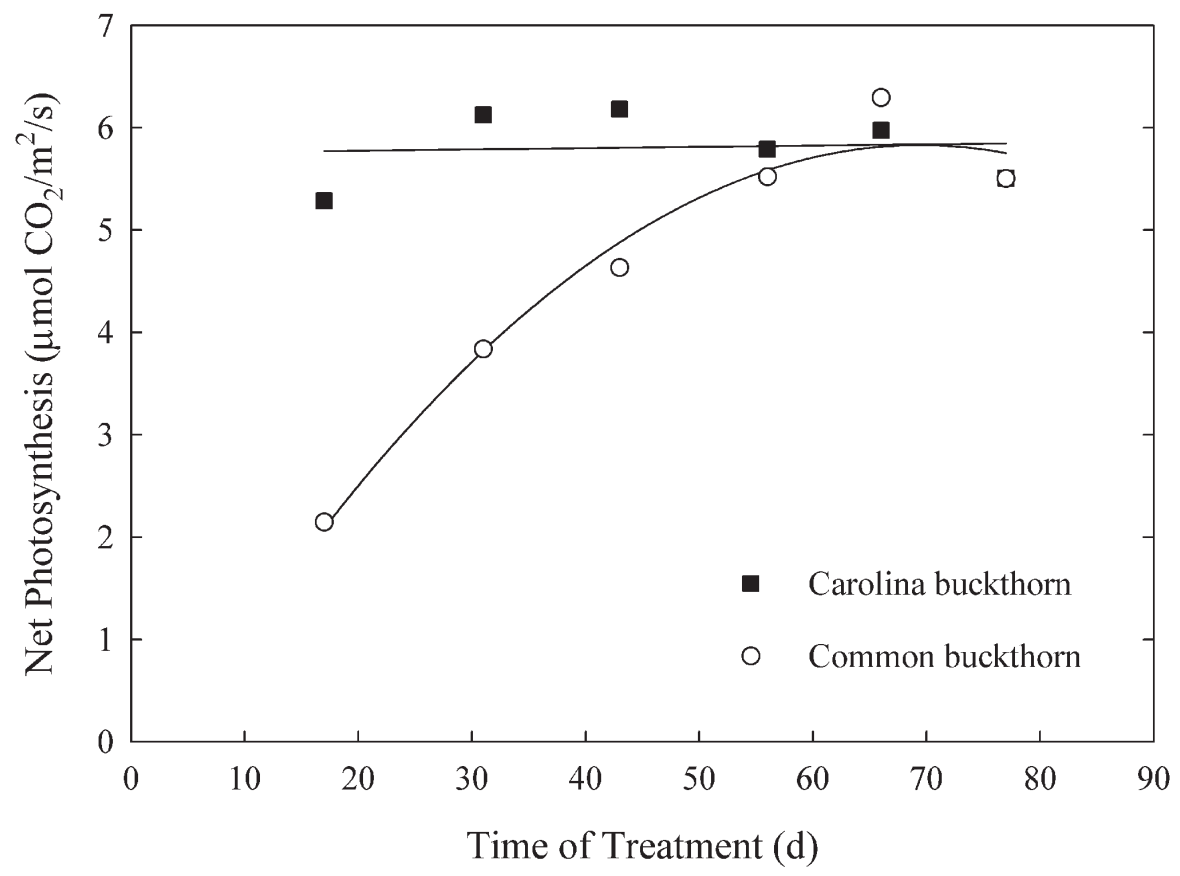

Fig. 1. Mean net photosynthesis of youngest, fully expanded leaves of partially flooded common buckthorn (y $=-0.7379+0.1892[$ day $\left.]-0.0014\left[\mathrm{day}^{2}\right], r^{2}=0.97\right)$ and partially flooded carolina buckthorn in the second experiment $\left(\mathrm{y}=5.749+0.0012\right.$ [day], $\left.r^{2}=0.01\right)$. Values are means of 30 plants of each species. 
wilt $15 \mathrm{~d}$ after treatment, which was followed by necrosis of the leaves and stems. Although the drought and wet treatments inhibited growth relative to the moist treatment, plants in all of these treatments appeared healthy and sustained glossy, green leaves.

Plants in the moderate-drought, moist, and wet treatments had similar mean photosynthetic rates (Table 1). Mean photosynthesis of plants in the moist treatment was more than double that of plants in the wet treatment, but there was considerable variation among plants. Regression analysis showed that the maximal rate of mean photosynthesis occurred when root zones contained $27 \%$ water by volume $(\mathrm{y}=-0.35+$ 23.9[water] - 44.3[water ${ }^{2}$ ], $\left.r^{2}=0.44\right)$. Root dry weight of plants in the wet treatment was $31 \%$ of that of plants in the moist treatment, whereas the flooded plants that died had no surviving roots (Table 1). Stem and leaf dry weights of moist-treated plants were greater than those of plants in the other treatments (Table 1). Plants in the wet and severe-drought treatments had lower total dry weights than did plants in the moist treatment. Plants subjected to moderate drought showed relative growth and net assimilation rates similar to those of plants in the moist treatment (Table 1).

Comparison of carolina buckthorn and common buckthorn. Net photosynthetic rate of partially flooded carolina buckthorn did not change over time; there was no evidence of a linear $(P=0.96)$ nor quadratic $(P=0.28)$ response (Fig. 1). However, the net photosynthetic rate of partially flooded common buckthorn was initially $59 \%$ less than that of carolina buckthorn but attained similar values by day 55 of treatment (Fig. 1). Common buckthorn initially showed leaf epinasty upon exposure to partial flooding but recovered as indicated by resumption of normal shoot development of new leaves distal to the epinastic leaves.

At the species level, the mean net photosynthetic rate of carolina buckthorn was $26 \%$ greater than that of common buckthorn $(P \leq$ $0.001)$ (Table 2$)$. Root $(P=0.03)$ and stem $(P$ $\leq 0.001$ ) dry weights of common buckthorn were greater than those of carolina buckthorn (Table 2). Total plant dry weight of common buckthorn also was greater than that of carolina buckthorn $(P=0.001)$ (Table 2$)$. The ratio of root to leaf dry weight of common buckthorn was $31 \%$ greater than that of carolina buckthorn $(P \leq 0.001)$ (Table 2).

At the treatment level, mean net photosynthetic rates of the two species did not differ within irrigation treatments. The actual rootzone water content among plants in the drought treatment averaged $7 \%$ when photosynthesis was measured and root zones were rehydrated. This led to reductions in photosynthesis of 52 and $68 \%$, respectively for carolina buckthorn and common buckthorn relative to rates of plants in the control treatment (Table 2). Total leaf area and root, stem, and total plant dry weights of control-treated common buckthorn were greater than those of common buckthorn subjected to drought and partial flooding and those of all carolina buckthorns. The drought and partial-flood treatments had similar effects on carolina buckthorn except that net photosynthesis of partially flooded carolina buckthorn was greater than that of drought-treated carolina buckthorn (Table 2). Root-to-leaf ratio of common buckthorn was greater across treatments and within the drought treatment than that of carolina buckthorn (Table 2). There were no differences in average net photosynthetic rate $(P=0.13)$ and total plant dry weight $(P=$ $0.90)$ among the three provenances of carolina buckthorn.

\section{Discussion}

Carolina buckthorn and common buckthorn fix carbon at rates that permit their survival in dry and moderately wet soils. However, common buckthorn appears to use carbon more efficiently than does carolina buckthorn, and common buckthorn undergoes adjustments in root zones that are extremely wet to optimize its growth and net photosynthesis. Such adjustments appear unnecessary for carolina buckthorns native to Missouri, Ohio, and Oklahoma to persist in soils with high water content. Thus, we conclude that regardless of provenance, carolina buckthorn is adapted to a wide range of soil-water conditions and is highly tolerant of both moderate degrees of drought and of root zones that are partially inundated.

Our approach to characterizing how water supply affects gas exchange and growth of carolina buckthorn was to make comparisons to common buckthorn, an aggressive invader of natural landscapes in the United States. Common buckthorn, like several other Rhamnus spp. (Archibold et al., 1997; Catling and Porebski, 1994), prefers moist soil. Among species-treatment combinations, total plant dry weight and leaf area were greatest for common buckthorns treated as controls (Table 2). Although the reduced growth of common buckthorns we treated with drought might seem contradictory to previous claims that the species grows well at dry sites (Gourley, 1985; USDA, 1948), the drought effects we observed should be considered within the context of the overall vigor and resilience of this species. Drought did reduce growth, but the weight and leaf area of drought-stressed common buckthorns were not different from those traits of carolina buckthorns that were provided uniform water in the control treatment (Table 2). Moreover, carolina buckthorn showed no differences in total dry weight and leaf area after being exposed to both drought and partial flooding during our second experiment, an indication that carolina buckthorn will withstand wet and dry soils in managed landscapes. Similar results have been reported for Acer rubrum L. (Abrams and Kubiske, 1990) and Nothofagus solandri (Hook. f.) Oerst. (Sun et al., 1995), which, like carolina buckthorn, are indigenous to dry and wet climates. The relatively small impact of drought compared to wetness and flooding during our first experiment (Table 1) indicates that carolina buckthorn is particularly adapted to dry soils. Hence, unless subsequent research shows that other factors such as invasiveness preclude its use, carolina buckthorn should be considered by producers and consumers as a large shrub or small tree adapted to both dry and wet soils. Sites where soils become completely inundated should be avoided, however.

Relationships between photosynthetic

Table 2. Mean photosynthetic rate, leaf area, plant dry weight, and root-to-leaf ratio of potted Rhamnus caroliniana Walt. (carolina buckthorn) and Rhamnus cathartica L. (common buckthorn) plants assigned to three treatments that were based on soil water content. Treatments were imposed on 1 Aug. 2001 and ended on 16 Oct. 2001. There were 45 single-plant replicates per species and 15 single-plant replicates per treatment.

\begin{tabular}{|c|c|c|c|c|c|c|c|}
\hline \multirow{3}{*}{$\begin{array}{l}\text { Species and } \\
\text { treatment }\end{array}$} & \multicolumn{7}{|c|}{ Dependent variable } \\
\hline & \multirow{2}{*}{$\begin{array}{l}\text { Photosynthetic rate } \\
\left(\mu \mathrm{mol} \mathrm{CO}{ }_{2} / \mathrm{m}^{2} / \mathrm{s}\right)\end{array}$} & \multirow{2}{*}{$\begin{array}{l}\text { Leaf area } \\
\left(\mathrm{cm}^{2}\right)\end{array}$} & \multicolumn{4}{|c|}{ Dry wt $(\mathrm{g})$} & \multirow{2}{*}{$\begin{array}{l}\text { Root-to-leaf } \\
\text { ratio }\end{array}$} \\
\hline & & & Root & Stem & Leaf & Total & \\
\hline \multicolumn{8}{|l|}{ Species across treatments } \\
\hline Rhamnus cathartica & $3.8 \mathrm{~B}$ & $583 \mathrm{~A}$ & $2.2 \mathrm{~A}$ & $2.3 \mathrm{~A}$ & $2.4 \mathrm{~A}$ & $6.8 \mathrm{~A}$ & $0.9 \mathrm{~A}$ \\
\hline \multicolumn{8}{|l|}{ Control treatment } \\
\hline Rhamnus caroliniana & $5.9 \mathrm{a}^{\mathrm{y}}$ & $652 \mathrm{~b}$ & $2.2 \mathrm{~b}$ & $1.0 \mathrm{c}$ & $3.1 \mathrm{a}$ & $6.4 \mathrm{~b}$ & $0.7 \mathrm{~b}$ \\
\hline Rhamnus cathartica & $5.2 \mathrm{a}$ & $854 \mathrm{a}$ & $3.1 \mathrm{a}$ & $3.3 \mathrm{a}$ & $3.6 \mathrm{a}$ & $10.0 \mathrm{a}$ & $0.9 \mathrm{ab}$ \\
\hline Rhamnus cathartica & $1.7 \mathrm{~b}$ & $478 \mathrm{bc}$ & $2.1 \mathrm{bc}$ & $2.0 \mathrm{~b}$ & $2.2 \mathrm{ab}$ & $6.3 \mathrm{~b}$ & $1.1 \mathrm{a}$ \\
\hline \multicolumn{8}{|l|}{ Partial-flood treatment } \\
\hline Rhamnus caroliniana & $5.8 \mathrm{a}$ & $479 \mathrm{bc}$ & $1.4 \mathrm{c}$ & $0.8 \mathrm{c}$ & $2.1 \mathrm{bc}$ & $4.3 \mathrm{~b}$ & $0.7 \mathrm{~b}$ \\
\hline Rhamnus cathartica & $4.7 \mathrm{a}$ & $418 \mathrm{c}$ & $1.3 \mathrm{c}$ & $1.4 \mathrm{bc}$ & $1.5 \mathrm{c}$ & $4.3 \mathrm{~b}$ & $0.9 \mathrm{ab}$ \\
\hline
\end{tabular}

${ }^{2}$ Species means within each column followed by the same capital letter are not different at $P \leq 0.05$ according to Tukey's honestly significant difference test.

yTreatment means within each column followed by the same lower-case letter are not different at $P \leq 0.05$ according to Tukey's honestly significant difference test. 
rate and accrual of dry weight illustrate the importance of the extensive leaf surface area of common buckthorn and suggest that common buckthorn uses resources more efficiently than does carolina buckthorn. Although at the species level carolina buckthorn had a photosynthetic rate that was $26 \%$ greater than that of common buckthorn, the comparatively low dry-matter accumulation of carolina buckthorn suggests that a relatively high portion of its fixed carbon was used for maintenance respiration. Accumulation of dry matter under soil-water conditions in our control treatment was $56 \%$ greater for common buckthorn than for carolina buckthorn, but mean photosynthetic rates for those plants did not differ (Table 2). The $31 \%$ greater total leaf surface area of control-treated common buckthorns compared to carolina buckthorns (Table2) may explain this finding, and common buckthorn also may have a comparatively high resource-use efficiency. Invasive species typically use resources more efficiently (Baruch and Goldstein, 1999; Bazzaz, 1986) and have higher rates of $\mathrm{CO}_{2}$ assimilation (Kloeppel and Abrams, 1995; Stratton and Goldstein, 2001) than do other species. The low assimilation rates at the species level for common buckthorn compared to carolina buckthorn that we found when measures were made at discrete times might be offset over a season in the field because leaves of common buckthorn emerge sooner and senesce later than those of carolina buckthorn (J.R. Stewart, unpublished data). In southern Wisconsin, 29\% of annual carbon gain of common buckthorn occurred before leaf emergence of Cornus racemosa Lam. (Harrington et al., 1989). The comparatively short seasonal time span during which they are foliated may represent a mechanism that restricts the capacity of carolina buckthorns to be as invasive as common buckthorns. Net photosynthesis of carolina buckthorn in the moist treatment of the first experiment (Table 1) was low relative to that of carolina buckthorn in the control treatment of our second experiment (Table 2). According to Larcher (2003), the average maximum values for net photosynthesis of deciduous trees under field conditions ranges from $6-12 \mu \mathrm{mol} \mathrm{CO} / \mathrm{m}^{2} / \mathrm{s}$. Our data from the second experiment approach this range, but all mean photosynthetic rates from the first experiment were less than $3 \mu \mathrm{mol}$ $\mathrm{CO}_{2} / \mathrm{m}^{2} / \mathrm{s}$. Although the explanation for these low means is uncertain, feedback inhibition due to root restriction within the pots may have been a factor. Such inhibition can cause a downward regulation of photosynthesis (Arp, 1991; Thomas and Strain, 1991). Also, the plants in the first experiment were grown in a soil-based medium that might have had a relatively high bulk density. This could have impaired photosynthesis (Handreck and Black, 2002) of carolina buckthorn in the moist treatment relative to that of carolina buckthorn in the control treatment of the second experiment, which were grown in a soil-less medium.

The adjustment in photosynthetic rate over time among partially flooded common buckthorns may have been due to hormonal responses within the plant (Bradford and
Yang, 1980). Transport of 1-aminocyclopropane-1-carboxylic acid from flooded root zones to shoots may explain our observations of leaf epinasty of common buckthorn (Taiz and Zeiger, 1998). It is also possible that the resumption of normal leaf development coincided with the generation of adventitious roots in response to hypoxic conditions induced by waterlogging (Chen et al., 2002; Schmull and Thomas, 2000). Carolina buckthorn evidently lacks the need for such adjustments and resists deleterious effects of wet and partially inundated soils. Most flooded plants show reduced net photosynthesis (Bradford, 1983; Pezeshki et al., 1996) and dry matter (Chen et al., 2002) as we observed for partially flooded common buckthorns (Fig. 1, Table 2). Mechanisms underlying the intriguing capacity of common buckthorn to recover from stresses during long exposure to partial root-zone inundation merit further investigation.

Although caution is needed when extending the results of experiments performed in a greenhouse to field-grown plants, several researchers using similar techniques have shown meaningful interspecific and intraspecific differences that are consistent in the greenhouse and the field (Myers and Landsberg, 1989; Schrader and Graves, 2000). Our work has demonstrated comparatively high leaf surface area combined with high ratios of root to leaf weight among common buckthorns. In addition, our data on common buckthorn suggest it uses resources more efficiently than does carolina buckthorn. This broadens the base of knowledge concerning factors that might contribute to the invasiveness of common buckthorn. These include dispersal of large annual seed crops by birds (Godwin, 1936; Kollmann and Pirl, 1995), vigorous plant development (Archibold et al., 1997), and possibly allelopathy (Boudreau and Wilson, 1992). While these traits have led to detrimental consequences for natural ecosystems in which common buckthorn has invaded, not all members of the Rhamnaceae are similarly problematic. For example, previous research indicates that Rhamnus californica Eschsch. (Paine et al., 1992; Schuch and Burger, 1997), Ceanothus griseus (Trel.) McMinn (Paine et al., 1992), and Ceanothus americanus L. (Martin et al., 1991) are stress-resistant plants that are not invasive. Carolina buckthorn appears similarly less prone to invasiveness and merits further evaluation for use as an ornamental plant for managed landscapes.

\section{Literature Cited}

Abrams, M.D. and M.E. Kubiske. 1990. Photosynthesis and water relations during drought in Acer rubrum L. genotypes from contrasting sites in central Pennsylvania. Functional Ecol. 4:727-733.

Archibold, O.W., D. Brooks, and L. Delanoy. 1997. An investigation of the invasive shrub European buckthorn, Rhamnus cathartica L., near Saskatoon, Saskatchewan. Can. Field-Nat. 111:617-621.

Arp, W.J. 1991. Effects of source-sink relations on photosynthetic acclimation to elevated $\mathrm{CO}_{2}$. Plant Cell Environ. 14:869-875.

Baruch, Z. and G. Goldstein. 1999. Leaf construc- tion cost, nutrient concentration, and net $\mathrm{CO}_{2}$ assimilation of native and invasive species in Hawaii. Oecologia 121:183-192.

Bazzaz, F.A. 1986. Life history of colonizing plants: Some demographic, genetic, and physiological features, p. 96-110. In: H.A. Mooney and J.A. Drake (eds.). Ecology of biological invasions of North America and Hawaii. Springer-Verlag, New York.

Berry, S.C., G.T. Varney, and L.B. Flanagan. 1997. Leaf $\delta^{13} \mathrm{C}$ in Pinus resinos $a$ and understory plants: variation associated with light and $\mathrm{CO}_{2}$ gradients. Oecologia 109:499-506.

Bradford, K.J. 1983. Effects of soil flooding on leaf gas exchange of tomato plants. Plant Physiol. 73:475-479.

Bradford, K.J. and S.F.Yang. 1980. Xylem transport of 1-aminocyclopropane-1-carboxylic acid, an ethylene precursor, in waterlogged tomato plants. Plant Physiol. 65:322-326.

Brown, C.L. and L.K. Kirkman. 1990. Trees of Georgia and adjacent states. Timber Press, Portland, Ore.

Boudreau, G. and D. Wilson. 1992. Buckthorn research and control at Pipestone National Monument. Restoration Mgt. Notes 10:94-95.

Catling, P.M. and Z.S. Porebski. 1994. The history of invasion and current status of glossy buckthorn, Rhamnus frangula, in southern Ontario. Can. Field-Nat. 108:305-310.

Chen, H., R.G. Qualls, and G.C. Miller. 2002. Adaptive responses of Lepidium latifolium to soil flooding: Biomass accumulation, adventitious rooting, aerenchyma formation and ethylene production. Environ. Expt. Bot. 48:119-128.

Foote, L.E. and S.B. Jones, Jr. 1989. Native shrubs and woody vines of the Southeast: Landscaping uses and identification. Timber Press, Portland, Ore.

Godwin, H. 1936. Studies in the ecology of Wicken Fen: III. The establishment and development of Fen Scrub (Carr). J. Ecol. 24:82-116.

Gourley, L.C. 1985. A study of the ecology and spread of buckthorn (Rhamnus cathartica L.) with particular reference to the University of Wisconsin Arboretum. MS thesis. Univ. Wisconsin-Madison.

Graves, W.R. 2001. Center-funded research at Iowa State on two native species. Landscape Plant News 12:2-6.

Handreck, K. and N. Black. 2002. Growing media for ornamental plants and turf. UNSW Press, Sydney.

Harper, J.L. 1977. Population biology of plants. Academic, London.

Harrington, R.A., B.J. Brown, and P.B. Reich. 1989. Ecophysiology of exotic and native shrubs in Southern Wisconsin. I. Relationship of leaf characteristics, resource availability, and phenology to seasonal patterns of carbon gain. Oecologia 80:356-367.

Kloeppel, B.D. and M.C. Abrams. 1995. Ecophysiological attributes of the native Acer saccharum and the exotic Acer platanoides in urban oak forests in Pennsylvania, USA. Tree Physiol. 15:739-746.

Kollmann, J. and M. Pirl. 1995. Spatial pattern of seed rain of fleshy-fruited plants in scrublandgrassland transition. Acta Oecol. 16:313-329.

Larcher, W. 2003. Physiological plant ecology: Ecophysiology and stress physiology of functional groups. Springer-Verlag, Berlin.

Martin, C.E., F.S. Harris, and F.J. Norman. 1991. Ecophysiological responses of $\mathrm{C}_{3}$ forbs and $\mathrm{C}_{4}$ grasses to drought and rain on a tallgrass prairie in northeastern Kansas. Bot. Gaz. 152:257-262.

Myers, B.J. and J.J. Landsberg. 1989. Water stress and seedling growth of two eucalypt species from contrasting habitats. Tree Physiol. 5:207-218. 
Paine, T.D., C.C. Hanlon, D.R. Pittenger, D.M. Ferrin, and M.K. Malinoski. 1992. Consequences of water and nitrogen management on growth and aesthetic quality of drought-tolerant woody landscape plants. J. Environ. Hort. 10:94-99.

Pezeshki, S.R., J.H. Pardue, and R.D. DeLaune. 1996. Leaf gas exchange and growth of flood-tolerant and flood-sensitive tree species with low soil redox conditions. Tree Physiol. 16:453-458.

SAS Institute, Inc. 1999-2001. SAS/STAT Software, version 8.2 of the SAS system for Windows. SAS Inst., Cary, N.C.

Schmull, M. and F.M. Thomas. 2000. Morphological and physiological reactions of young deciduous trees $($ Quercus robur L., Q. petraea [Matt.]Liebl., Fagus sylvatica $\mathrm{L}$.) to waterlogging. Plant Soil 225:227-242.

Schrader, J.A. and W.R. Graves. 2000. Seed germination and seedling growth of Alnus maritima from its three disjunct populations. J. Amer. Soc. Hort. Sci. 125:128-134.

Schuch, U.K. and D.W. Burger. 1997. Water use and crop coefficients of woody ornamentals in containers. J. Amer. Soc. Hort. Sci. 122:727-734.

Soper, J.H. and M.L. Heimburger. 1982. Shrubs of Ontario. Royal Ontario Museum, Toronto.

Stratton, L.C. and G. Goldstein. 2001. Carbon uptake, growth and resource-use efficiency in one invasive and six native Hawaiian dry forest tree species. Tree Physiol. 21:1327-1334.

Sun, O.J., G.B. Sweet, D. Whitehead, and G.D. Buchan. 1995. Physiological responses to water stress and waterlogging in Nothofagus species. Tree Physiol. 15:629-638.

Taiz, L. and E. Zeiger. 1998. Plant physiology. Sinauer Assoc., Sunderland, Mass.

Thomas, R.B. and B.R. Strain. 1991. Root restriction as a factor in photosynthetic acclimation of cotton seedlings grown in elevated carbon dioxide. Plant Physiol. 96:627-634.

U.S. Department of Agriculture. 1948. Woody-plant seed manual. USDA Misc. Publ. 654 